\title{
Short-term and long-term effects of the toxic dinoflagellate Alexandrium minutum on the copepod Acartia clausi
}

\author{
M. Frangópulos ${ }^{1, *}$, C. Guisande ${ }^{1}$, I. Maneiro ${ }^{1}$, I. Riveiro ${ }^{1}$, J. Franco ${ }^{2}$ \\ ${ }^{1}$ Facultad de Ciencias del Mar, Universidad de Vigo, Apartado 874, 36200 Vigo, Spain \\ ${ }^{2}$ Instituto de Investigaciones Marinas (CSIC), Eduardo Cabello 6, 36208 Vigo, Spain
}

\begin{abstract}
Several experiments were performed to determine the effects of cell toxin concentration, composition and toxicity of Alexandrium minutum on ingestion rate, egg production, hatching success and naupliar fitness of the copepod Acartia clausi. A combination of A. minutum and nontoxic algae (Prorocentrum micans, Tetraselmis suecica and Isochrysis galbana) was used as food. Copepods ingested a higher amount of A. minutum cells as the concentration of these toxic dinoflagellates increased, and also in response to decreasing total food concentration available for the copepods. A positive relationship was obtained between $A$. minutum cells ingested by copepods and total toxin concentration per copepod. Hatching success and naupliar production were lower when copepods ingested a higher amount of toxic dinoflagellates. This negative effect could has been due to the accumulated toxins in the egg and copepod tissues, and was higher when A. minutum had a higher cell concentration of GTX1. Finally, the results obtained from nauplii incubated with $T$. suecica and I. galbana showed that nauplii hatched from females fed non-toxic food (T. suecica and I. galbana) reached copepodite stage earlier than those nauplii hatched from females fed with a combined of toxic (A. minutum) and non-toxic (T. suecica and I. galbana) food.
\end{abstract}

KEY WORDS: Dinoflagellate $\cdot$ Copepod $\cdot$ Toxins $\cdot$ PSP $\cdot$ Reproduction

\section{INTRODUCTION}

It is well known that copepods can be negatively affected by toxic marine dinoflagellates (Turner \& Tester 1997). Although enhanced mortality due to direct ingestion of toxic algae is known to occur in copepods (Carlsson et al. 1995, Bagøien et al. 1996), evidence of such mortality is limited. More frequently, the effects of toxins on copepods may be sublethal, such as reductions in food intake, food assimilation or fecundity (Gill \& Harris 1987, Uye \& Takamatsu 1990, Dutz 1998, Teegarden 1999).

Copepods may exhibit reduced feeding and/or fecundity after ingestion of toxic phytoplankton either

*E-mail:mfr@uvigo.es due to behavioural rejection prior to ingestion or physiological impairment due to ingested toxins. Earlier studies supported a physiological basis for the observed suppression of feeding rate (Ives 1985, 1987, Huntley et al. 1986), whereas later studies have concluded that discriminatory feeding selection is important in the grazing response of copepods to toxic dinoflagellates, either by trial-and-error consumption of harmful phytoplankton that allow grazers to learn which species should be avoided (Uye \& Takamatsu 1990), or by behavioural rejection prior to ingestion (Teegarden 1999). Other studies have however shown that phycotoxins are not crucial in determining feeding interactions between toxic dinoflagellates and copepods (Gill \& Harris 1987, Teegarden \& Cembella 1996, Dutz 1998). The reduced fecundity observed in copepods exposed to toxic dinoflagellates has been 
also explained either as a result of feeding avoidance (Uye \& Takamatsu 1990, Nejstgaard \& Solberg 1996) or physiological impairment (Gill \& Harris 1987, Dutz 1998).

Dutz (1998) showed in Acartia clausi fed Alexandrium lusitanicum that gross growth-efficiency of copepods can also be negatively affected through the ingestion of toxic dinoflagellates. He explained this negative effect of ingested toxins as being due to either negative effects on food assimilation or an enhanced energy expenditure of females for detoxification purposes.

Finally, Turner et al. (1998) suggested that marine phycotoxins might also negatively affect future generations of copepods: offspring might be indirectly affected by toxins ingested by their parents. It has been suggested that hatching success in copepods may be negatively influenced by toxic dinoflagellates ingested by females (Nejstgaard \& Solberg 1996, Turner et al. 1998), although the results obtained in both studies showed no significant differences between treatments.

Much of the variation observed in the effects of phycotoxins on copepod feeding and/or reproduction is probably related to the considerable variation in cellular toxin potency, composition and concentration (Turner \& Tester 1997). Intracellular levels of toxins can vary within a single algal clone (Chang et al. 1997), depending upon culture conditions (Boyer et al. 1987, Flynn et al. 1996, Parkhill \& Cembella 1999) or the presence of toxic intracellular bacteria (Gallacher et al. 1997). An additional problem is that the differing responses observed in copepod species to specific combinations of toxic and non-toxic prey phytoplankters (Turriff et al. 1995, Teegarden \& Cembella 1996, Teegarden 1999), are likely to lead to differing grazing patterns (Turner \& Tester 1997).

Many aspects of the interaction between toxic dinoflagellates and copepods therefore still remain unclear, especially the effects on copepods of cell toxin concentration, composition and toxicity, the effects of a different combination of toxic and non-toxic algal species available to the copepods and the effects on the offspring of toxin ingested by the parents. We therefore carried out a study to determine the effects of a different combination of toxic and non-toxic algal species on ingestion rate, egg production, hatching success and naupliar fitness of the copepod Acartia clausi. The toxic dinoflagellate Alexandrium minutum was used because it often cooccurs with A. clausi in Ría de Vigo (Spain).

\section{MATERIALS AND METHODS}

Zooplankton collection. Zooplankton were collected by vertically integrated tows at a field station $39 \mathrm{~m}$ deep, located in the Ría de Vigo, Spain $\left(42^{\circ} 13.3^{\prime} \mathrm{N}\right.$, $8^{\circ} 47.7^{\prime} \mathrm{W}$ ), an area that has experienced blooms of toxic and non-toxic Alexandrium spp. (Centro de Calidad del Medio Marino de la Xunta de Galicia, Vilaxoan, monitoring reports). Samples were transported to the laboratory within $2 \mathrm{~h}$ of collection, and adult Acartia clausi were sorted out for the experiments.

Algal species. The algal species used as food and their diameter and carbon and nitrogen content per cell is shown in Table 1. Filtering efficiency is a function of the diameter of the algal species, for Acartia clausi feeding on Alexandrium minutum, Prorocentrum micans and Tetraselmis suecica it is $100 \%$, but only $<10 \%$ on Isochrysis galbana (Donaghay \& Small 1979). The strain of A. minutum (A1 IV) used in this study was isolated from the Galician rias and came from a long-established population cultured in the Instituto Español de Oceanografía (Vigo). This toxic strain only contains Gonyautoxins 1, 2, 3 and 4 (GTX1 to 4) (Franco et al. 1994). Copepods were fed algae at exponential phase because toxin composition is constant in exponential growth-phase cultures (Franco et al. 1994, Parkhill \& Cembella 1999). The carbon and nitrogen contents, of the phytoplankton species were determined from subsamples of exponentially growing cultures, filtered on pre-combusted GF/F filters at low pressure, dried at $70^{\circ} \mathrm{C}$, and combusted in a Fisons EA-1108. Cell carbon and nitrogen were calculated by counts of 15 replicate subsamples on an inverted microscope. Sulphanilamide was used as the standard.

Experimental design. Two experiments were performed. In Expt I, abundance of Alexandrium minutum varied while abundance of Tetraselmis suecica and Isochrysis galbana was kept constant. In Expt II, abundance of A. minutum was kept constant and abundance of Prorocentrum micans, T. suecica and I. galbana varied between the different experimental treat-

Table 1. Algal food species. Cell diameter measured with inverted microscope (Alexandrium minutum and Prorocentrum micans) and equivalent spherical diameter (Tetraselmis suecica and Isochrysis galbana) measured by Coulter counter, and carbon and nitrogen content of algal species used in experiments (means $\pm \mathrm{SD}, \mathrm{n}=$ number of determinations)

\begin{tabular}{|lccccr|}
\hline Species & $\mathrm{n}$ & $\begin{array}{c}\text { Cell diam. } \\
(\mu \mathrm{m})\end{array}$ & $\mathrm{n}$ & \multicolumn{1}{c|}{$\begin{array}{c}\text { c cell } \\
(\mathrm{pg})\end{array}$} & \multicolumn{1}{c|}{$\begin{array}{c}\mathrm{N} \mathrm{cell}^{-1} \\
(\mathrm{pg})\end{array}$} \\
\hline Alexandrium minutum & 55 & $27.8 \pm 2.4$ & 21 & $445.4 \pm 12.8$ & $127.5 \pm 4.1$ \\
Prorocentrum micans & 50 & $38.3 \pm 1.6$ & 21 & $1061.3 \pm 25.4$ & $241.2 \pm 5.1$ \\
Tetraselmis suecica & & $8.5 \pm 2.4$ & 12 & $99.9 \pm 2.8$ & $9.6 \pm 0.4$ \\
Isochrysis galbana & & $3.7 \pm 1.5$ & 12 & $11.1 \pm 1.2$ & $2.0 \pm 0.2$ \\
\hline
\end{tabular}


Table 2. Initial carbon concentrations $\left(C_{\mathrm{i}}\right)$ and average carbon concentrations $\left(C_{\mathrm{x}}\right)$ of algal species on day grazing experiment was

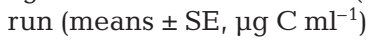

\begin{tabular}{|c|c|c|c|c|c|c|c|c|c|c|}
\hline \multirow{2}{*}{$\begin{array}{l}\text { Experi- } \\
\text { mental } \\
\text { conc. }\end{array}$} & \multicolumn{2}{|c|}{ Alexandrium minutum } & \multicolumn{2}{|c|}{ Prorocentrum micans } & \multicolumn{2}{|c|}{$\begin{array}{l}\text { Algal species } \\
\text { Tetraselmis suecica }\end{array}$} & \multicolumn{2}{|c|}{ Isochrysis galbana } & \multicolumn{2}{|c|}{ Total } \\
\hline & $C_{\mathrm{i}}$ & $C_{\mathrm{x}}$ & $C_{\mathrm{i}}$ & $C_{\mathrm{x}}$ & $C_{\mathrm{i}}$ & $C_{\mathrm{x}}$ & $C_{\mathrm{i}}$ & $C_{\mathrm{x}}$ & $C_{\mathrm{i}}$ & $C_{\mathrm{x}}$ \\
\hline \multicolumn{11}{|c|}{ Expt I } \\
\hline A & $0.51 \pm 0.01$ & $0.48 \pm 0.01$ & 0.0 & 0.0 & $3.04 \pm 0.11$ & $2.97 \pm 0.06$ & $0.88 \pm 0.03$ & $0.84 \pm 0.01$ & $4.43 \pm 0.11$ & $4.29 \pm 0.06$ \\
\hline $\mathrm{B}$ & $0.28 \pm 0.01$ & $0.24 \pm 0.01$ & 0.0 & 0.0 & $2.29 \pm 0.11$ & $2.35 \pm 0.06$ & $0.65 \pm 0.01$ & $0.74 \pm 0.03$ & $3.25 \pm 0.11$ & $3.32 \pm 0.06$ \\
\hline $\mathrm{C}$ & $0.12 \pm 0.01$ & $0.10 \pm 0.01$ & 0.0 & 0.0 & $1.99 \pm 0.09$ & $2.30 \pm 0.11$ & $0.68 \pm 0.02$ & $0.71 \pm 0.03$ & $2.82 \pm 0.09$ & $3.11 \pm 0.12$ \\
\hline $\mathrm{D}$ & $0.02 \pm 0.01$ & $0.02 \pm 0.01$ & 0.0 & 0.0 & $1.89 \pm 0.06$ & $1.78 \pm 0.05$ & $0.67 \pm 0.01$ & $0.56 \pm 0.04$ & $2.60 \pm 0.06$ & $2.36 \pm 0.06$ \\
\hline \multicolumn{11}{|c|}{ Expt II } \\
\hline A & $0.64 \pm 0.01$ & $0.70 \pm 0.01$ & $1.05 \pm 0.03$ & $1.06 \pm 0.01$ & $4.32 \pm 0.13$ & $4.70 \pm 0.06$ & $1.24 \pm 0.06$ & $1.24 \pm 0.02$ & $7.26 \pm 0.15$ & $7.69 \pm 0.07$ \\
\hline $\mathrm{B}$ & $0.50 \pm 0.02$ & $0.54 \pm 0.01$ & 0.0 & 0.0 & $2.52 \pm 0.05$ & $2.70 \pm 0.04$ & $0.88 \pm 0.02$ & $0.89 \pm 0.01$ & $3.90 \pm 0.06$ & $4.13 \pm 0.04$ \\
\hline $\mathrm{C}$ & 0.0 & 0.0 & $1.10 \pm 0.09$ & $0.91 \pm 0.01$ & $2.80 \pm 0.14$ & $2.55 \pm 0.05$ & $1.03 \pm 0.02$ & $0.84 \pm 0.01$ & $4.93 \pm 0.17$ & $4.30 \pm 0.05$ \\
\hline $\mathrm{D}$ & $0.53 \pm 0.03$ & $0.55 \pm 0.01$ & 0.0 & 0.0 & $0.92 \pm 0.10$ & $1.02 \pm 0.01$ & $0.33 \pm 0.02$ & $0.37 \pm 0.01$ & $1.78 \pm 0.10$ & $1.94 \pm 0.02$ \\
\hline $\mathrm{E}$ & $0.53 \pm 0.04$ & $0.52 \pm 0.01$ & 0.0 & 0.0 & $0.55 \pm 0.03$ & $0.64 \pm 0.01$ & $0.15 \pm 0.01$ & $0.19 \pm 0.01$ & $1.23 \pm 0.05$ & $1.35 \pm 0.02$ \\
\hline
\end{tabular}

ments. Table 2 shows the initial $\left(C_{\mathrm{i}}\right)$ and average $\left(C_{\mathrm{x}}\right)$ cell concentrations obtained in each experiment on the day the grazing experiment was run (6th day of the experiment). The carbon concentration in each experiment ensured that the potential for selection was not affected by possible food limitation which might constrain grazers to consume less palatable prey (Teegarden 1999).

Egg production and hatching estimation. From the sample collected in the field, between 35 and 40 adult females of Acartia clausi were sorted and transferred to individual $25 \mathrm{ml}$ beakers containing some of the experimental food concentrations. Copepods were kept with constant shaking $(60 \mathrm{rpm})$ at $15^{\circ} \mathrm{C}$ under a 12:12 h light:dark cycle. Each day the copepods were transferred to fresh phytoplankton suspensions at the experimental concentration. In both experiments, copepod mortality ranged between 1 and $3 \% \mathrm{~d}^{-1}$ in all experimental food concentrations, with the exception of Concentration D in Expt II, which was $8 \% \mathrm{~d}^{-1}$. After 3 d acclimatisation, eggs were collected daily and counted for an additional $3 \mathrm{~d}$. The eggs daily produced by 7 to 10 females were pooled, so there were 3 replicates of each experimental food concentration. From each replicate, 150 eggs produced by females every day were incubated for a further $48 \mathrm{~h}$ before fixation and counting of hatched nauplii and the remaining unhatched eggs. The remaining eggs were used to estimated egg toxin-concentration. Egg production, naupliar production and hatching success were estimated as the mean of the values obtained during the $3 \mathrm{~d}$ of the experiment.

Grazing estimation. Grazing trials were performed on the 6th day of the experiment. Between 13 and 15 replicates with 1 copepod in each $25 \mathrm{ml}$ beaker were used for each experimental food concentration. Seven replicate control containers and initial containers with- out copepods were prepared at the same time. Initial container samples were preserved immediately at the start of the experiment. Grazing experiments were run for $16 \mathrm{~h}$ in the same temperature, light and shaking conditions given above. Copepods were checked at the end of the experiment, and the samples were preserved with $4 \%$ formaldehyde for phytoplankton cellcounting with an inverted microscope. Frost's (1972) equations were used to calculate $C_{\mathrm{x}}$ in control containers and copepod ingestion rates in experimental containers.

Offspring fitness. Nauplii hatched from eggs produced on the 6th day of the experiment by females fed non-toxic food (Food Concentration C of Expt II: Table 2), and nauplii hatched from females fed Alexandrium minutum and non-toxic food (Food Concentration B of Expt II: Table 2) were grown at low (approx. $0.6 \mu \mathrm{g} \mathrm{C} \mathrm{ml}{ }^{-1}$ Tetraselmis suecica and $0.2 \mu \mathrm{g} \mathrm{C} \mathrm{ml}^{-1}$

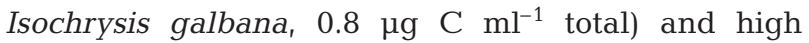
(approx. $1 \mu \mathrm{g} \mathrm{C} \mathrm{ml}^{-1}$ T. suecica and $0.4 \mu \mathrm{g} \mathrm{C} \mathrm{ml}^{-1}$ I. galbana, $1.4 \mu \mathrm{g} \mathrm{C} \mathrm{ml}^{-1}$ total) food concentrations. For each group of nauplii and experimental concentration, 6 replicates containing 30 nauplii in $30 \mathrm{ml}$ petri dishes of experimental cell mixtures were prepared. Nauplii were transferred every $2 \mathrm{~d}$ to fresh phytoplankton, and the number of nauplii still alive was recorded. The experiment was run until some of the nauplii reached Copepodite Stage I, and the remaining nauplii were used to estimate naupliar body length.

Toxin analyses. To estimate daily cell toxin variation of Alexandrium minutum in both experiments, algal cells were collected daily on pre-combusted $13 \mathrm{~mm}$ $\mathrm{GF} / \mathrm{F}$ Whatman filters and stored at $-80^{\circ} \mathrm{C}$ in ultracentrifuge plastic tubes and lyophilised. Four hundred $\mu \mathrm{l}$ of $0.05 \mathrm{M}$ acetic acid was added to the lyophilised material and the sample was homogenised using a pipette tip adapted to fit the shape of the vial. The sample was 
shaken, followed by freezing twice. Finally, the extract was centrifuged at $4000 \mathrm{rpm}$ for $10 \mathrm{~m}$ twice, after which $200 \mu \mathrm{l}$ of the supernatant was carefully collected with a Hamilton syringe, and stored at $-20^{\circ} \mathrm{C}$. Egg and copepod toxin contents were only analysed on copepods from the experimental food concentrations of Expt II. On the 6th day of the experiment, 20 copepods were transferred from each experimental food concentration to distilled water, and were immediately isolated with a known volume of distilled water (no higher than $40 \mu \mathrm{l}$ ). Eggs collected daily from the 3rd to the 6th day were transferred from each experimental food concentration to distilled water and were immediately isolated with a known volume of distilled water (no higher than $150 \mu \mathrm{l}$ ). Eggs from the same experimental food concentration were always grouped in the same sample; the final number of eggs in the samples ranged between 566 and 1090. Samples of both copepods and eggs were stored at $-80^{\circ} \mathrm{C}$ in ultracentrifuge plastic tubes and lyophilised; $125 \mu \mathrm{l}$ of acetic acid $0.05 \mathrm{M}$ was added to the lyophilised material followed by the same steps as above.

Analysis of the paralytic shellfish poisoning (PSP) toxins by high-performance liquid chromatography (HPLC) with fluorescence detection was performed following a modification of the method of Oshima et al. (1989) described by Franco \& Fernández (1993). Chromatographic profiles of Alexandrium minutum cells were determined by quatruple injections of $20 \mu \mathrm{l}$ of extracts (diluted with $0.05 \mathrm{M}$ acetic acid, as necessary). Chromatographic profiles of copepods were determined by only a single injection of $35 \mu$ of the extracts. Toxins from the National Research Council of Canada (Halifax) were used as toxin standards.

Toxicity of Alexandrium minutum, in saxitoxin equivalents (STXeq), was calculated from the HPLC chromatograms. The toxin concentrations were multiplied by a toxin-specific conversion factor to yield toxicity. The specific toxicity-conversion factors of the individuals toxins were adopted from Oshima (1995) based upon empirical mouse bioassay data determined using purified standards, and assuming the conversion factor of 1 mouse unit $(\mathrm{MU})=0.23 \mu \mathrm{g}$ STXeq for the ddy mouse strain: 567.6 (GTX1), 205.2 (GTX2), 364.3 (GTX3) and 414.7 (GTX4).

\section{RESULTS}

Table 3 shows the specific toxic composition, total toxin per cell and total cell toxicity of Alexandrium minutum in Expts I and II. The strain of A. minutum used in this study is at the low end of the toxicity range observed for this species (Chang et al. 1997). There were no significant differences in toxin composition, total toxin per cell and total cell toxicity of $A$. minutum over the course of the experiments (ANOVA, $F_{5,11}<3.2$, $\mathrm{p}>0.05$ ), which is consistent with the numerous reports of constant toxin composition in exponential phase cultures (Franco et al. 1994, Parkhill \& Cembella 1999). In both experiments, A. minutum had a very similar toxic composition. There were no significant differences in the amount of GTX2, GTX3 and GTX4 per cell, total toxin per cell and total cell toxicity between the 2 experiments (ANOVA, $F_{1,5}<2.8$, p > 0.1 , but there were significant differences in the concentration of GTX1 per cell (ANOVA, $F_{1,5}=50.8$, $\mathrm{p}<0.001$ ).

The ingestion rates of Acartia clausi in response to increasing food concentrations of Alexandrium minutum, in mixed concentrations of toxic and non-toxic algae, showed that copepods preyed actively on toxic dinoflagellates, and no signs of reduced ingestion or satiation by the toxic cells were observed (Fig. 1, slope differed from zero, $F_{1,57}=113.9, \mathrm{r}^{2}=0.67, \mathrm{p}<0.001$ ). However, when the abundance of A. minutum remained constant, A. clausi ingested higher amounts of A. minutum at lower total food concentrations (Fig. 2; slope differed from zero, $F_{1,56}=103.9, \mathrm{r}^{2}=0.65, \mathrm{p}<$ 0.001). Using data from both experiments, a stepwise regression showed that ingestion rate of $A$. clausi on A. minutum ( $\left(\right.$, in $\mu \mathrm{g} \mathrm{C}$ copepod $\left.{ }^{-1} \mathrm{~d}^{-1}\right)$ was significantly related to $A$. minutum abundance $\left(A\right.$, in $\left.\mu \mathrm{g} \mathrm{ml}^{-1}\right)$ and the abundance of non-toxic ( $N t)$ phytoplankton species (in $\left.\mu \mathrm{g} \mathrm{C} \mathrm{ml}^{-1}\right)_{i} I=4.152+16.689 \mathrm{~A}-1.817 N t_{,} F_{2,114}=$ $\left.276.8, \mathrm{r}^{2}=0.83, \mathrm{p}<0.001\right)$.

The HPLC analyses of concentrated extracts from copepods exposed to Alexandrium minutum revealed the presence of gonyautoxins in the copepod and egg tissues (GTX1, GTX2, GTX3 and GTX4), but saxitoxin, neosaxitoxin and decarbamoyl analogues were absent. Fig. 3 shows that as copepods ingested a higher

Table 3. Alexandrium minutum. Specific toxin composition of gonyautoxins (GTX1-4, mean \pm SE, fmol cell ${ }^{-1}$ ), total toxin per cell (combined GTX1, GTX2, GTX3 and GTX4, mean $\pm \mathrm{SE}$, fmol cell ${ }^{-1}$ ) and total cell toxicity (mean \pm SE, fg STXeq cell ${ }^{-1}$ ) of alga used as food Expts I and II (STXeq = saxitoxin equivalents). Data presented in order of decreasing toxin content

\begin{tabular}{|lccccrr|}
\hline Experiment & GTX4 & GTX1 & GTX3 & GTX2 & Total toxin & Cell toxicity \\
\hline Expt I & $0.612 \pm 0.049$ & $0.146 \pm 0.018$ & $0.017 \pm 0.003$ & $0.010 \pm 0.002$ & $0.785 \pm 0.055$ & $345.2 \pm 24.7$ \\
Expt II & $0.654 \pm 0.053$ & $0.074 \pm 0.006$ & $0.014 \pm 0.004$ & $0.007 \pm 0.001$ & $0.704 \pm 0.069$ & $300.9 \pm 29.3$ \\
\hline
\end{tabular}




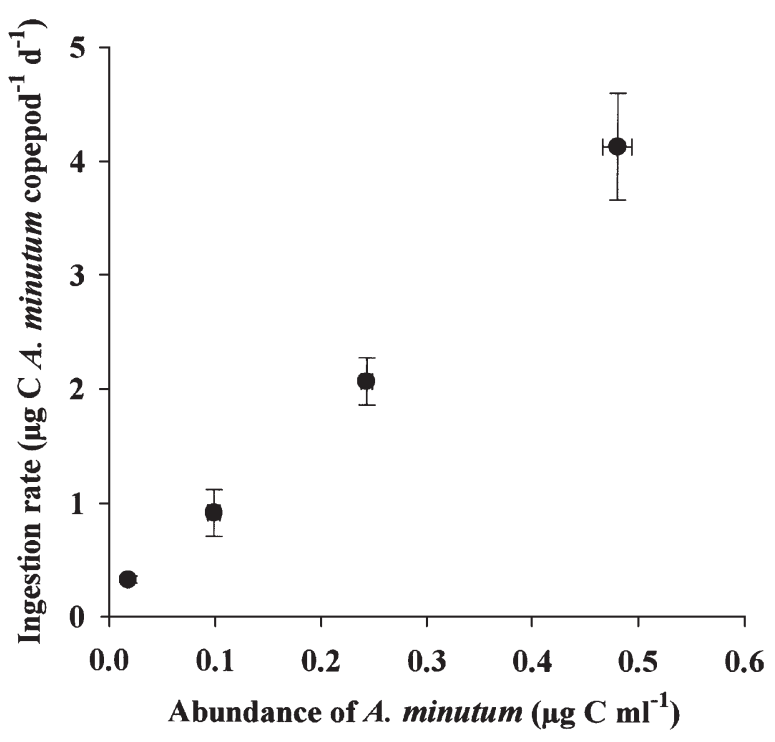

Fig. 1. Acartia clausi. Ingestion rates of Alexandrium minutum as a function of $A$. minutum abundance. Data are means $\pm \mathrm{SE}$

amount of $A$. minutum, the toxin concentration in the copepods increased (slope different from zero, $F_{1,56}=$ 107.4, $\left.\mathrm{r}^{2}=0.66, \mathrm{p}<0.001\right)$.

There was a significant relationship between daily egg production (Fig. 4a, slope differed from zero, $\left.F_{1,22}=9.8, \mathrm{r}^{2}=0.31, \mathrm{p}=0.005\right)$ and daily naupliar production (Fig. 4b, slope differed from zero, $F_{1,22}=16.9$, $\mathrm{r}^{2}=0.44, \mathrm{p}<0.001$ ) and total food concentration in Expts I and II. There were no significant differences in neither egg production (ANCOVA, $F_{1,4}=1.86, \mathrm{p}>0.2$ ) or naupliar production (ANCOVA, $F_{1,4}=0.29, \mathrm{p}>0.5$ ) between experiments.

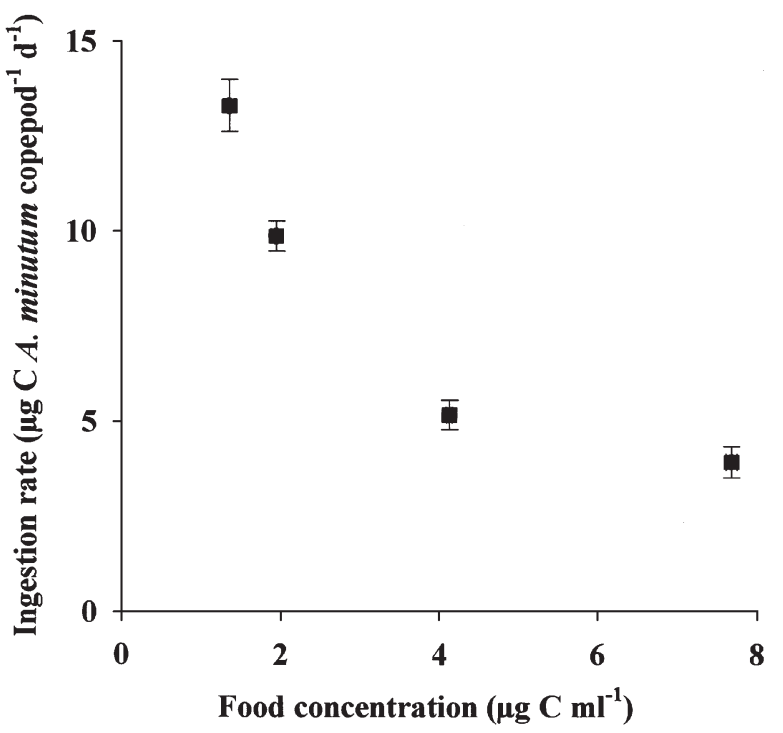

Fig. 2. Acartia clausi. Ingestion rates of Alexandrium minutum as a function of total food-carbon concentration. (Data are means $\pm \mathrm{SE}$ )

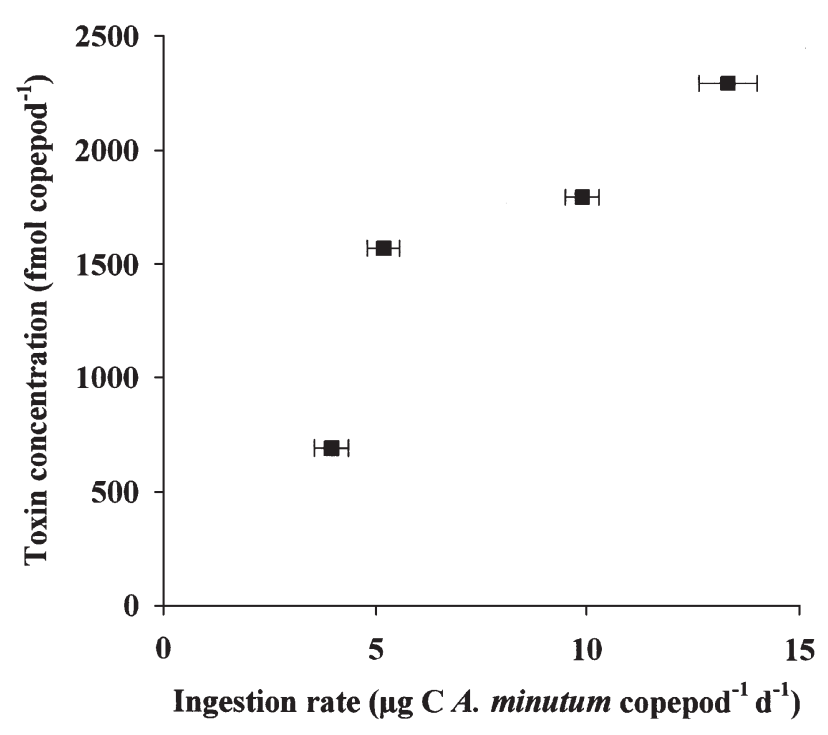

Fig. 3. Acartia clausi. Total toxic concentration (gonyautoxins, GTX1-4) in tissues of copepod as a function of ingestion rate of Alexandrium minutum. Data are means $\pm 1 \mathrm{SE}$

Table 4 shows daily egg production and daily naupliar production of Acartia clausi in experimental food concentrations with similar carbon concentrations. There were no significant differences between egg production of females fed toxic and non-toxic algae at a similar food concentration (ANOVA, $\mathrm{F}_{1,7}=3.6, \mathrm{p}=$ $0.099)$, but there were differences in naupliar production (ANOVA, $F_{1,7}=9.7, \mathrm{p}=0.017$ ).

Hatching success was not related to food concentration, but appeared to be negatively influenced by the amount of Alexandrium minutum ingested by the copepods (Fig. 5). In both experiments hatching success was related to ingestion rate of $A$. minutum (for Expt I, slope differed from zero, $F_{1,10}=12.8, \mathrm{r}^{2}=0.56$, $\mathrm{p}=0.005$; for Expt II, slope differed from zero, $F_{1,13}=$ $\left.46.8, r^{2}=0.78, p<0.001\right)$, and there were also significant differences between slopes of the regressions obtained in experiments (ANCOVA, $F_{1,5}=19.7, \mathrm{p}=0.006$ ). Hatching success was also significantly related to the

Table 4. Acartia clausi. Mean \pm SE daily egg production (eggs female $\mathrm{e}^{-1} \mathrm{~d}^{-1}$ ) and daily naupliar production (nauplii female ${ }^{-1}$ $\mathrm{d}^{-1}$ ) in Food Concentrations B and C of Expt II, and Food Concentration A of Expt I

\begin{tabular}{|lcc|}
\hline $\begin{array}{l}\text { Experimental } \\
\text { conc. }\end{array}$ & $\begin{array}{c}\text { Egg } \\
\text { production }\end{array}$ & $\begin{array}{c}\text { Naupliar } \\
\text { production }\end{array}$ \\
\hline $\begin{array}{l}\text { Expt I } \\
\text { A }\end{array}$ & $32.1 \pm 4.0$ & $24.2 \pm 3.6$ \\
Expt II & & \\
B & $28.7 \pm 1.9$ & $22.8 \pm 1.5$ \\
C & $38.8 \pm 4.2$ & $34.2 \pm 4.0$ \\
\hline
\end{tabular}



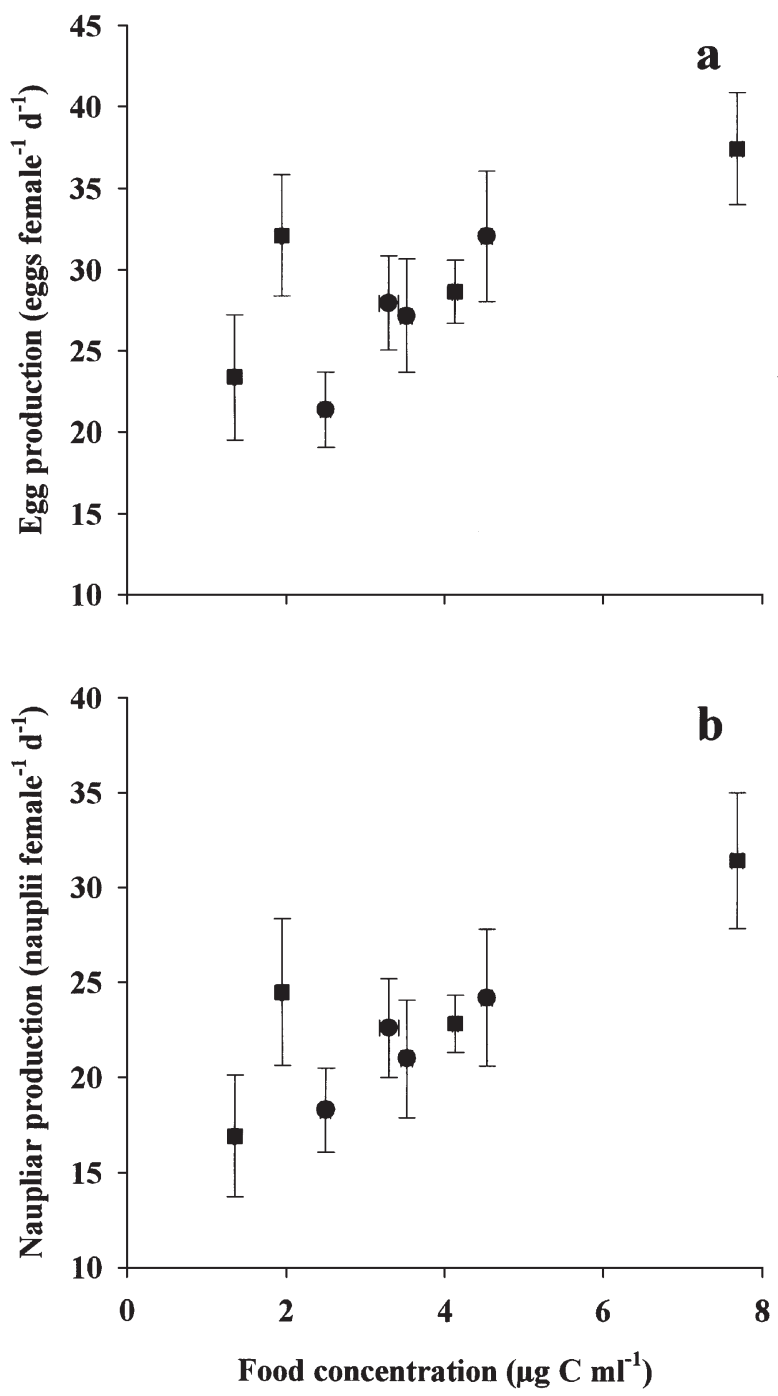

Fig. 4. Acartia clausi. (a) Daily egg production and (b) daily naupliar production of copepod as a function of total food-

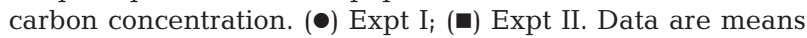
$\pm 1 \mathrm{SE}$

toxin ingested by the copepods (Fig. 6a, slope differed from zero, $F_{1,13}=35.4, \mathrm{p}<0.001$ ), and to egg toxin concentration (Fig. 6b, slope differed from zero, $F_{1,7}=$ $\left.125.8, \mathrm{r}^{2}=0.95, \mathrm{p}<0.001\right)$. Because of the low number of eggs collected it was not possible to detect toxins in the eggs from Food Concentrations D and E (Expt II). Therefore, although the relationship between hatching success and egg toxin concentration is significant, as only 2 toxic treatments were available, this relationship should be interpreted with caution.

The results of the offspring fitness experiment showed naupliar survival to be low at both low and high food concentrations (Fig. 7), and the values were within the range of naupliar survival observed for copepods in culture (Lopez 1991). Naupliar survival appeared to be

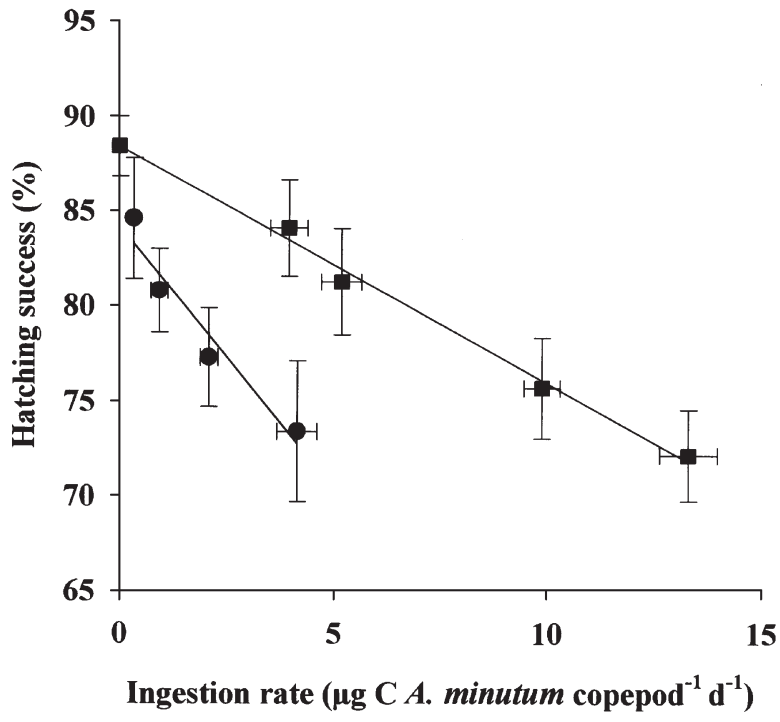

Fig. 5. Acartia clausi. Relationship between hatching success and ingestion rate of Alexandrium minutum. (•) Expt I;

(匹) Expt II. Data are means $\pm 1 \mathrm{SE}$

higher during the initial phase of the experiment on nauplii hatched from females fed non-toxic food than on nauplii hatched from females fed toxic food, both at low and high food concentrations (Fig. 7). Nevertheless, on Day 12 naupliar survival (Table 5) was not significantly different for nauplii hatched from females fed non-toxic food than for those hatched from females fed toxic food at both high (ANOVA, $F_{1,10}=1.8, \mathrm{p}=$ 0.202 ) and low (ANOVA, $F_{1,8}=0.3, p=0.588$ ) food concentrations. At Day 12, there were no significant differences in naupliar body length at the lowest food concentration (ANOVA, $F_{1,13}=1.7, p=0.212$ ), but there were significant differences at the highest food concentration (ANOVA, $F_{1,56}=7.8, p=0.007$ ). This is probably the reason why at the highest food concentration, nauplii hatched from females fed non-toxic food reached copepodite stage earlier than nauplii hatched from females fed toxic food (Table 5). However, because of the high naupliar mortality, the number of data may have been too low to estimate possible differences in development rate.

\section{DISCUSSION}

Our results showed that Acartia clausi fed on the toxic strain of Alexandrium minutum used in this study (Fig. 1). The relationship between ingestion rate and A. minutum abundance in the feeding experiments was similar to those reported for Acartia clausi feeding on a low-toxicity strain of Alexandrium lusitanicum (1.56 pg STXeq cell ${ }^{-1}$, Dutz 1998). Moreover, grazing 

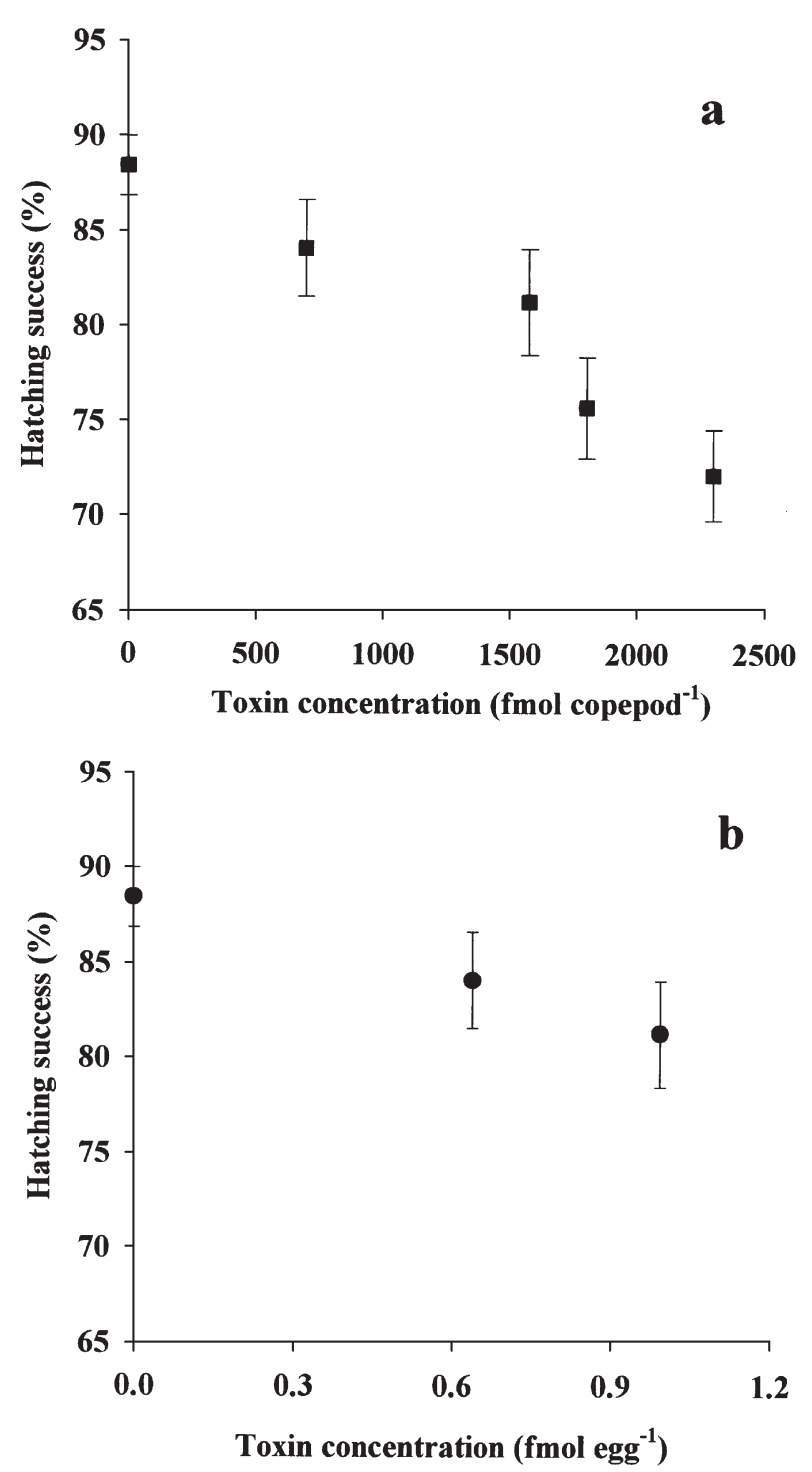

Fig. 6. Acartia clausi. Relationship between hatching success (means $\pm 1 \mathrm{SE}$ ) and total toxic concentration (gonyautoxins, GTX1-4) in tissues of (a) copepods and (b) eggs

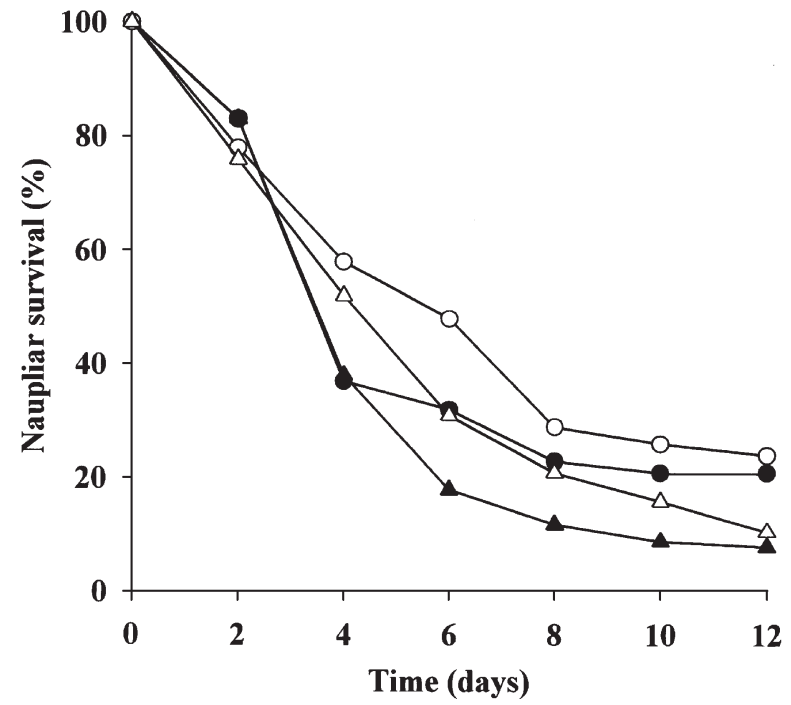

Fig. 7. Acartia clausi. Survival curves of nauplii hatched from females fed toxic (Food Concentration B of Expt II, filled symbols) and non-toxic (Food Concentration C of Expt II, open symbols) food. Nauplii were fed 2 different food concentrations; (1) mixture of Tetraselmis suecica and Isochrysis galbana: approx. $0.6 \mu \mathrm{g} \mathrm{C} \mathrm{ml}^{-1} \mathrm{~T}$. suecica and $0.2 \mu \mathrm{g} \mathrm{C} \mathrm{ml}^{-1}$ I. galbana, $0.8 \mu \mathrm{g} \mathrm{C} \mathrm{ml}^{-1}$ total (triangles); (2) approx. $1 \mu \mathrm{g} \mathrm{C}$ $\mathrm{ml}^{-1}$ T. suecica and $0.4 \mu \mathrm{g} \mathrm{C} \mathrm{ml}^{-1}$ I. galbana, $1.4 \mu \mathrm{g} \mathrm{C} \mathrm{ml}^{-1}$ total (circles). All SEs for means of naupliar survival were $<5.6$

enhanced energy expenditure of the females necessary to cope with the ingested toxins.

The high ingestion rates observed could be explained by the low-toxicity of the strain used in this study. Therefore, as mentioned by Teegarden (1999), nontoxic or low-toxicity dinoflagellates species are highly susceptible to grazing losses. Although previous studies have shown copepod fecundity to be negatively affected by the ingestion of toxic dinoflagellates (Gill \& Harris 1987, Dutz 1998, Turner et al. 1998), our results are in agreement with those studies that found toxic pressure on A. minutum was higher in response to reduced food concentration of non-toxic species (Fig. 2), probably in order to maintain basic daily rations.

This study also showed non-satiated feeding of Acartia clausi on Alexandrium minutum, similar to the observation of Dutz (1998) in Acartia clausi feeding also on a low toxic strain of Alexandrium lusitanicum. Dutz suggested that this non-satiated feeding could be because the ratio energy-obtained to biomass-ingested is low, perhaps due to the interference of ingested toxins with the assimilatory processes and/or an
Table 5. Acartia clausi. Mean \pm SE naupliar body length $(\mu \mathrm{m})$, naupliar survival (\%) and percent of copepodites of $12 \mathrm{~d}$ old that hatched from females fed toxic (Food Concentration B of Expt II: Table 2), and non-toxic (Food Concentration C of Expt II: Table 2) food, and cultured at 2 different experimental food concentrations

\begin{tabular}{|llccc|}
\hline $\begin{array}{l}\text { Naupliar } \\
\text { food conc. }\end{array}$ & $\begin{array}{c}\text { Female } \\
\text { food conc. }\end{array}$ & $\begin{array}{c}\text { Naupliar } \\
\text { size }\end{array}$ & $\begin{array}{c}\text { Naupliar } \\
\text { survival }\end{array}$ & $\begin{array}{c}\% \\
\text { copepodite }\end{array}$ \\
\hline $1.4 \mu \mathrm{g} \mathrm{C} \mathrm{ml}^{-1}$ & Non-toxic & $236.5 \pm 5.8$ & $23.9 \pm 2.3$ & $12.6 \pm 9.2$ \\
& Toxic & $219.2 \pm 3.0$ & $20.6 \pm 1.2$ & 0 \\
$0.8 \mathrm{\mu} \mathrm{C} \mathrm{ml}^{-1}$ & Non-toxic & $220.0 \pm 6.1$ & $10.7 \pm 4.4$ & 0 \\
& Toxic & $210.0 \pm 6.9$ & $8.0 \pm 2.3$ & 0 \\
& & & & \\
\hline
\end{tabular}


algae to have no influence on egg production (Turner et al. 1997). However, the present study revealed that low-toxicity strains of dinoflagellates can also control grazing pressure. Hatching success fell as copepods ingested higher amounts of Alexandrium minutum cells (Fig. 5), perhaps because of the high amount of toxins ingested by the copepods, with especially high concentrations in the eggs (Fig. 6). This is not surprising because it is known that the chemical composition of freshly spawned copepod eggs is sensitive to the maternal diet (Guisande \& Harris 1995, Guisande et al. 1999, Laabir et al. 1999). For this reason, reduced hatching success in copepods has been associated with nutritional inadequacy (Ianora et al. 1992, Ianora \& Poulet 1993, Guisande et al. 1999, Laabir et al. 1999) or inhibitors (see Ban et al. 1997). Moreover, this study has also shown that nauplii hatched from females fed non-toxic food reached the copepodite stage earlier than nauplii hatched from females fed toxic food. This means a delay to attainment of first reproduction, and hence a reduced net reproductive rate of the next generation through ingestion of toxic cells by parental females.

In addition to decreasing hatching success with increasing toxin ingestion by the copepods, hatching success was lower in Expt I than in Expt II. The only difference between both experiments was the concentration of GTX1 present in Alexandrium minutum cells. This could be explained by the fact that GTX1 is the most toxic of the toxins in the PSP group (Oshima 1995). However, despite the differences observed in GTX1 cell concentrations between both experiments, there were no significant differences in total cell toxicity of A. minutum between experiments. As it is not known how gonyautoxins affect egg development, it is not clear whether the differences in hatching success observed between experiments arose from changes in the specific toxicity of the cells, or, was due to other factors such as differences in consumption on alternative non-toxic foods.

Dinoflagellate toxin production is often assumed to have evolved as a deterent to grazers (Turner et al. 1998). In the copepod Tigriopus californicus, Shaw et al. (1997) showed that a mixture of soluble PSP toxins could act as feeding deterrents. Many studies, including ours, have however shown that toxic dinoflagellates are ingested by copepods (Turner et al. 1998), which casts doubt on the advantage of toxin production if the dinoflagellates cannot repel all possible grazers. Teegarden (1999) concluded that the presence of toxins in a clone of Alexandrium fundyense conferred the definite advantage of reducing that dinoflagellate's palatability or desirability compared to a nontoxic Alexandrium species. This does not cause the dinoflagellate to be avoided or to be selected against by all grazer species. It confirms that grazing interaction between copepods and toxic dinoflagellates depends on the specific combination between copepod and toxic phytoplankton species (Teegarden \& Cembella 1996, Teegarden 1999).

This study, however, showed that the loss of cells to grazers can be fairly well compensated by negative effects on grazer offspring-fitness. As predicted by Turner et al. (1998), toxic dinoflagellates can clearly adversely affect future generations of copepods. In the case of Acartia clausi, the ingestion of toxic cells by the copepod is accompanied by short-term (reduced hatching success) and long-term (reduced naupliar growth rate) impairments. According to the kin-selection theory, an individual can increase its gene representation in future generations by helping close relatives, who share copies of its genes which are identical by descent. As reproduction in Alexandrium minutum occurs mainly by simple cell division, future effects on grazers after a cell has already been consumed is of evolutionary significance. However, it is necessary to point out that Teegarden (1999) showed the tolerance to paralytic shellfish poisoning (PSP) toxins to be species-specific. In his study, Acartia tonsa showed a strong aversion to PSP toxins, whereas Eurytemora herdmani was tolerant of PSP toxin consumption. Therefore, it is possible that some copepod species are able to cope with ingested toxins and hence do not suffer the negative effects on offspring fitness observed in A. clausi.

To produce a high amount of toxins is probably energetically expensive, but the advantages are a possible discriminatory feeding behaviour against the toxic dinoflagellates and, hence, a possible increased grazing pressure on alternate non-toxic competitors of dinoflagellates. Low toxin production is energetically cheaper, and has sublethal effects on copepods if toxic cells are ingested by them. However, it implies a loss of cells, a long-term profit and, finally, it can also be beneficial for potential competitors of dinoflagellates. This possible trade-off between high and low toxin production could be of importance to the interaction between copepods and toxic dinoflagellates.

Acknowledgements. We thank J. T. Turner for the revision of the manuscript. This research was supported by Projects MAR96-1822 and MAR95-1849, a grant from the Chilean Government to M.F., an FPU grant to I.M., and a grant from FUNDACIÓN PROVIGO to I.R.

\section{LITERATURE CITED}

Bagøien E, Miranda A, Reguera B, Franco JM (1996) Effects of two paralytic shellfish toxin producing dinoflagellates on the pelagic harpacticoid copepod Euterpina acutifrons. Mar Biol 126:361-369 
Ban S and 22 others (1997) The paradox of diatom-copepod interactions. Mar Ecol Prog Ser 157:287-293

Boyer GL, Sullivan JJ, Andersen RJ, Harrison PJ, Taylor FJR (1987) Effects of nutrient limitation on toxin production and composition in the marine dinoflagellate Protogonyaulax tamarensis. Mar Biol 96:123-128

Carlsson P, Granéli E, Finenko G, Maestrini SY (1995) Copepod grazing on a phytoplankton community containing the toxic dinoflagellate Dinophysis acuminata. J Plankton Res 17:1925-1938

Chang FH, Anderson DM, Kulis DM, Till DG (1997) Toxin production of Alexandrium minutum (Dinophyceae) from the Bay of Plenty, New Zealand. Toxicon 35:393-409

Donaghay PL, Small LF (1979) Food selection capabilities of the estuarine copepod Acartia clausi. Mar Biol 52:137-146

Dutz J (1998) Repression of fecundity in the neritic copepod Acartia clausi exposed to the toxic dinoflagellate Alexandrium lusitanicum: relationship between feeding and egg production. Mar Ecol Prog Ser 175:97-107

Flynn KJ, Flynn K, John EH, Reguera B, Reyero MI, Franco JM (1996) Changes in toxins, intracellular and dissolved free amino acids of the toxic dinoflagellate Gymnodinium catenatum in response to changes in inorganic nutrients and salinity. J Plankton Res 18:2093-2111

Franco JM, Fernández P (1993) Separation of PSP toxins by reversed phase high performance liquid chromatography, with postcolumn reaction and fluorimetric detection. Chromatographia 35:613-620

Franco JM, Fernández P, Reguera B (1994) Toxin profiles of natural populations and cultures of Alexandrium minutum Halim from Galician (Spain) coastal waters. J Appl Phycol $6: 275-279$

Frost BW (1972) Effects of size and concentration of food particles on the feeding behaviour of the marine planktonic copepod Calanus pacificus. Limnol Oceanogr 17:805-815

Gallacher S, Flynn KJ, Franco JM, Brueggemann EN, Hines HB (1997) Evidence for production of paralytic shellfish toxins by bacteria associated with Alexandrium spp. (Dinophyta) in culture. Appl Environ Microbiol 63:239-245

Gill CW, Harris RP (1987) Behavioural responses of the copepods Calanus helgolandicus and Temora longicornis to dinoflagellate diets. J Mar Biol Assoc UK 67:785-801

Guisande C, Harris R (1995) Effect of total organic content of eggs on hatching success and naupliar survival in the copepod Calanus helgolandicus. Limnol Oceanogr 40: 476-482

Guisande C, Maneiro I, Riveiro I (1999) Homeostasis in the essential amino acid composition of the marine copepod Euterpina acutifrons. Limnol Oceanogr 44:691-696

Huntley ME, Sykes P, Rohan S, Marin V (1986) Chemicallymediated rejection of dinoflagellate prey by the copepods Calanus pacificus and Paracalanus parvus: mechanism, occurrence and significance. Mar Ecol Prog Ser 28:105-120

Ianora A, Poulet SA (1993) Egg viability in the copepod Temora stylifera. Limnol Oceanogr 38:1615-1626

Ianora A, Mazzocchi MG, Grottoli R (1992) Seasonal fluctuations in fecundity and hatching success in the planktonic copepod Centropages typicus. J Plankton Res 14: 1483-1494

Ives JD (1985) The relationship between Gonyaulax tamarensis cell toxin levels and copepod ingestion rates. In: Ander-

Editorial responsibility: Otto Kinne (Editor), Oldendorf/Luhe, Germany son DM, White AW, Baden DG (eds) Toxic dinoflagellates. Elsevier, New York, p 413-418

Ives JD (1987) Possible mechanisms underlying copepod grazing responses to levels of toxicity in red tide dinoflagellates. J Exp Mar Biol Ecol 112:131-145

Laabir M, Poulet SA, Cueff A, Ianora A (1999) Effect of diet on levels of amino acids during embryonic and naupliar development of the copepod Calanus helgolandicus. Mar Biol 134:89-98

Lopez MDG (1991) Molting and mortality depend on age and stage in naupliar Calanus pacificus: implication for development time of field cohorts. Mar Ecol Prog Ser 75:79-89

Nejstgaard JC, Solberg PT (1996) Repression of copepod feeding and fecundity by the toxic haptophyte Prymnesium patelliferum. Sarsia 81:339-344

Oshima Y (1995) Post-column derivatization HPLC methods for paralytic shell fish poisons. In: Hallegraeff GM, Anderson DM, Cembella AD (eds) Manual on harmful marine microalgae. IOC (Intergovtl Oceanogr Comm) Manuals and guides, No. 33; UNESCO, Rome, p 81-94

Oshima Y, Sugino K, Yasumoto T (1989) Latest advances in HPLC analysis of paralytic shellfish toxins. In: Natori S, Hashimoto K, Ueno Y (eds) Mycotoxins and phycotoxins. Elsevier, Amsterdam, p 319-326

Parkhill JP, Cembella AD (1999) Effects of salinity, light and inorganic nitrogen on growth and toxigenicity of the marine dinoflagellate Alexandrium tamarense from northeastern Canada. J Plankton Res 21:939-955

Shaw BA, Andersen RJ, Harrison PJ (1997) Feeding deterrent and toxicity effects of apo-fucoxanthinoids and phycotoxins on a marine copepod (Tigriopus californicus). Mar Biol 128:273-280

Teegarden GJ (1999) Copepod grazing selection and particle discrimination on the basis of PSP toxin content. Mar Ecol Prog Ser 181:163-176

Teegarden GJ, Cembella AD (1996) Grazing of toxic dinoflagellates, Alexandrium spp., by adult copepods of coastal Maine: implications for the fate of paralytic shellfish toxins in marine food webs. J Exp Mar Biol Ecol 196:145-176

Turner JT, Tester PA (1997) Toxic marine phytoplankton, zooplankton grazers, and pelagic food webs. Limnol Oceanogr 42:1203-1214

Turner JT, Lincoln, JA, Cembella AD (1997) Effects of toxic and non-toxic dinoflagellates on copepod grazing, egg production and egg hatching success. In: Reguera B, Blanco J, Fernández ML, Wyatt T (eds) Harmful algae. Xunta de Galicia, Vigo, and Intergovernmental Oceanographic Commission (IOC) of UNESCO, Paris, p 379-381

Turner JT, Tester PA, Hansen PJ (1998) Interactions between toxic marine phytoplankton and metazoan and protistan grazers. In: Anderson DM, Cembella AD, Hallegraeff GM (eds) Physiological ecology of harmful algal blooms. Springer-Verlag, Berlin, p 453-474 (NATO ASI [Ser G 41: Ecol Sciences])

Turriff N, Runge JA, Cembella AD (1995) Toxin accumulation and feeding behaviour of the planktonic copepod Calanus finmarchicus exposed to the red-tide dinoflagellate Alexandrium excavatum. Mar Biol 123:55-64

Uye S, Takamatsu K (1990) Feeding interactions between planktonic copepods and red-tide flagellates from Japanese coastal waters. Mar Ecol Prog Ser 59:97-107

Submitted: December 6, 1999; Accepted: March 21, 2000

Proofs received from author(s): August 21, 2000 